\title{
The Great Depression and the Making of Turkish-Syrian Border, 1921-1939
}

\author{
Ramazan Hakkı Öztan^ (D) \\ Department of History, University of Neuchâtel, Neuchatel, Switzerland \\ ${ }^{\star}$ Corresponding author. E-mail: ramazan.oztan@unine.ch
}

(Received 8 February 2019; revised 20 September 2019)

\begin{abstract}
This article explores how the Great Depression in 1929 led to the expansion of illicit circuits globally, and examines the ways in which the introduction of anti-smuggling campaigns came to consolidate the border regimes in Turkey and French Syria. The global economic downturn in the late 1920s led states to embrace protectionist measures such as heightened tariffs and import quotas, all designed to protect local industries and maintain a favorable trade balance. The introduction of such measures, however, often resulted in the emergence of highly profitable illicit circuits, including in the borderland between Turkey and Syria. Here, a sturdy coalition of producers, shop owners, smugglers, trackers, and peddlers began to smuggle into Turkey a range of goods from silk textiles to cigarette papers, while funneling out narcotics into Syria. By seeking the global trajectories of such commodity flows, this article examines the impact of these borderland mobilities on the making of Turkey's southern border by exploring the local and bureaucratic responses to a rapidly changing world economic order in the aftermath of the Great Depression.
\end{abstract}

Keywords: Turkey; Syria; Mandates; borderlands; smuggling; tariffs

When the stock market crashed in New York City on 29 October 1929 and set in motion a crisis that was to last well into the mid-1930s, those who lived in the borderlands between Turkey and Syria were unaware that the economic downturn originating thousands of miles away would soon transform their local socioeconomic conditions in drastic ways. Until 1929, they lived in an area with a border that existed largely only on paper, with limited enforcement of cross-border checks that hardly qualified as a border regime. This was in part because the boundary separating Turkey from Syria did not follow a natural barrier such as a river-Lord Curzon's "most natural" of all frontiers-but rather went along the famous Berlin-Baghdad railway. ${ }^{1}$ With large swathes of lands on both sides of the tracks, the border was easy to traverse for the trespasser and difficult to monitor for the bureaucrat. As one journalist saw it, in some parts it was even impossible to distinguish where the border actually began and where it came to an end. ${ }^{2}$ Close to 900 kilometers long, Turkey's southern border, in the words of the Turkish minister of interior at the time, was "complex and unnatural," cutting across communities that had intermingled since Ottoman times. ${ }^{3}$

Neither Turkey nor the French mandatory authorities in Syria did much throughout the 1920s to institute any meaningful mechanisms of surveillance along the border. Consumed by internal political problems, both countries lacked state capacity to fully monitor the border. Turkey was roiled by political uncertainty at a time when a series of events from secret plots to open rebellions tested the consolidation of power under the Kemalists. French authorities, on the other hand, were constantly challenged by the demands of Syrian nationalists critical of mandatory rule, while also feeling insecure about Turkish

\footnotetext{
${ }^{1}$ Lord Curzon of Kedleston, Frontiers (Oxford, UK: Clarendon Press, 1908), 20.

${ }^{2}$ Mümtaz Faik, "Cenup Hududu Hain, Sinsi bir Huduttur," Tan (1 January 1937), 2.

${ }^{3}$ Turkish Republican Archives of the Prime Ministry (hereafter BCA), 30.10, 180-244-6, 5 December 1931, 11.
} 
designs, since Ankara stood ready to reap further benefits from developments that could trouble the French presence along the border. ${ }^{4}$ This lasted until 1925, when the Sheikh Said Rebellion and the Great Syrian Revolt tested the footholds of Turkey and France in the region, forcing both powers to extend greater state presence to their borderlands. Only in the fall of 1925 did interstate commissions begin to convene to demarcate the Turkish-Syrian border that had previously been defined only ambiguously in the Franklin-Bouillon Agreement of $1921 .^{5}$

Although this process of demarcation resulted in a bilateral compromise on the site of the physical boundary by the early 1930s, the Turkish-Syrian border continued to remain porous, with ongoing cross-border flow for two reasons. First, unlike Turkey's borders with Iraq and Iran, which cut across mountainous terrain with low population density, the border with Syria ran through heavily populated agricultural lands. Second, the border divided the Ottoman province of Aleppo in two, thereby separating Aleppo, the center of transit trade, from its southeastern Anatolian market. ${ }^{6}$ Challenging the regional economic connections that had been cultivated for centuries under Ottoman rule, the border was porous in part because of economic pressures. As one Turkish official acknowledged in 1931, although a decade had passed since the institution of the border, former economic practices continued to be decisive in the Turkish-Syrian borderlands due to "former habits and familiarities, and mutual ties of trust and feelings of security" shared by the former Ottoman subjects who now lived, at least technically, on different sides of "national borders." In the early 1930s, for instance, goods were still exchanged in the region with the old Ottoman silver and gold coins, instead of the national paper currencies issued by the new capitals. ${ }^{7}$

While former imperial economic practices ensured the porousness of the Turkish-Syrian border, I locate the consolidation of the border regime in the government responses to the economic challenges brought about by the Great Depression beginning in the late 1920s. This was when governments across the globe, informed by burgeoning notions of economic warfare and national survival, began to increase protective tariffs and introduce import quotas to guard their indigenous industries. These protectionist measures, coupled with disparities in tariff regimes between neighboring countries, quickly made smuggling an attractive option for local populations who were greatly impoverished by the global depression. As contraband trade skyrocketed to unprecedented volumes from the early 1930s onward, governments eager to protect their economies began to frame illicit transactions as an urgent national problem demanding greater vigilance. The porous Turkish-Syrian border accordingly became an important test bed for new principles of national economy, with implementation of a range of anti-smuggling measures and introduction of increased surveillance practices and border controls throughout the 1930s.

\section{Illicit Circuits: Before the Great Depression}

Smuggling was not a novelty brought to the Turkish-Syrian borderlands by the Great Depression, as illicit exchange had begun to flourish in the region soon after institution of the border. Because the early 1920s were defined by liberal customs policies, however, the tariff differences between Turkey and Syria remained moderate enough to discourage the illegal exchange of a wider range of goods. Smugglers instead tended to limit their operations to the commodities whose production, sale, and distribution were regulated by monopolies. Monopolies often charged higher prices on the Turkish side of the border, creating price differences attractive enough to animate cross-border illicit exchange. In particular, commodities such as cigarette papers, matches, salt, and sugar offered handsome profits once smuggled into Turkey, where smugglers could then purchase sheep and tobacco to traffic back to Syria. ${ }^{8}$

\footnotetext{
${ }^{4}$ The Turkish-Syrian borderlands were therefore typical, as defined by Jeremy Adelman and Stephen Aron. See Adelman and Aron, "From Borderlands to Borders: Empires, Nation-States, and the Peoples in between in North American History," American Historical Review, 104 no. 3 (1999): 814-41.

${ }^{5}$ Soheila Mameli-Ghaderi, "Le tracé de la frontière entre la Syrie et la Turquie (1921-1929)," Guerres Mondiales et Conflits Contemporains 207 (2002-2003): 125-38.

${ }^{6}$ Amit Bein, Kemalist Turkey and the Middle East: International Relations in the Interwar Period (Cambridge, UK: Cambridge University Press, 2017), 42.

${ }^{7}$ BCA, 30.10, 180-244-6, 5 December 1931, 1.

${ }^{8}$ Martin van Bruinessen, Agha, Shaikh and State: The Social and Political Structures of Kurdistan (London: Zed Books, 1992), 190.
} 
Ankara itself acknowledged the situation and pointed to the monopolies as the main reason for the smuggling boom in the early 1920s. Yet, in line with the generic bureaucratic script they had inherited from the Ottomans, reactions of the Turkish bureaucrats to illicit trade during those years were largely episodic, if not entirely ineffective. ${ }^{9}$ In late 1923, the governor of Gaziantep complained that illicit circuits often operated with the active involvement of Turkish border guards and customs officials, most of whom were individuals with their own interests and an utter lack of patriotic feelings. ${ }^{10}$ Similarly, rumors of mismanagement of Istanbul customs found extensive coverage in the newspapers but rarely translated into the formulation of new policies, at least in the first half of the 1920s. ${ }^{11}$ Because the monopolies that had existed since the late Ottoman period were owned by foreign interests, the Turkish government was first and foremost more interested in taking them over. Only after the nationalization of the Régie Company in 1925 did Ankara seek to expand key domestic industries to reduce the appeal of smuggled goods. This included, for instance, the creation of tobacco processing workshops in places like Urfa and Bitlis, close to Turkey's southern border. ${ }^{12}$

The bid for heightened border security and anti-smuggling measures by Turkish authorities was further strengthened when Ankara felt politically threatened by the outbreak of the Sheikh Said Rebellion in early 1925, a two-month Kurdish uprising affecting southeastern Anatolia. The rebels' cross-border networks quickly prompted Turkish authorities to announce a stricter regime of surveillance along the Syrian border to curtail the influx of print propaganda, and Ankara also took the opportunity to press the French authorities for further action. ${ }^{13}$ This growing interest in a secure border also led the Turkish authorities to cease their tacit support of the activities of armed bands that had challenged French jurisdiction in the area since the early 1920s. ${ }^{14}$ The Law for the Protection of Order (Takrir-i Sükūn Kanunu), legislated in the midst of the rebellion, had endowed the government with extraordinary powers that Ankara began to use freely to address standing issues of border security. In September 1925, for example, when a customs agent was badly beaten after confiscating sizable tobacco and sugar contraband in the Eastern Mediterranean, Ankara decided to make an example out of the smugglers by referring the case to the notorious independence tribunals. ${ }^{15}$

In May 1926, a commission was set up to develop firm measures against the illicit circuits of Turkey's southern border and the Aegean Sea. ${ }^{16}$ In the Aegean Sea, authorities discovered that crews aboard the government-run ferries that traveled from the islands to Istanbul were smuggling cigarette paper and decks of cards inside the life buoys and stashing colognes, cognac, cannabis, sugar, and rice in staff cabins. ${ }^{17}$ At Turkey's southern border the illicit economy took various forms, often featuring the tacit approval, if not the direct participation, of officials. In Dörtyol, soldiers who were discharged from their units were caught smuggling cigarette paper, matches, and cologne as they traveled via the railroad. ${ }^{18}$ In another instance, authorities discovered 100 kilograms of sugar in the midst of military cargo en route from Akçakale to Urfa, smuggled in from Syria. ${ }^{19}$ Although Turkey and the French concluded a customs agreement with provisions that sought to tackle contraband in 1926, the Turkish consulate in Aleppo reported in April 1927 that "passengers could easily travel without a passport from one

\footnotetext{
${ }^{9}$ For the Ottoman precedents, see Ramazan Hakkı Öztan, “Tools of Revolution: Global Military Surplus, Arms Dealers and Smugglers in the Late Ottoman Balkans, 1878-1908," Past \& Present 237, no. 1 (2017): 167-95.

${ }^{10} \mathrm{BCA}, 30.10,262-764-15,12$ December 1923, 4.

${ }^{11}$ BCA 230.0, 82-71-2, 8 July 1924, 1.

${ }^{12}$ BCA, 30.10, 179-238-10, 8 August 1933, 20-33.

${ }^{13}$ BCA, 30.18.1.1, 13-14-19, 18 March 1925.

${ }^{14}$ Seda Altuğ and Benjamin Thomas White, "Frontières et pouvoir d'état: La frontière turco-syrienne dans les années 1920 et 1930," Vingtième Siècle: Revue d'histoire, 103 no. 3 (2009): 91-104.

${ }^{15}$ BCA, 30.18.1.1, 15-59-14, 16 September 1925, 1, 3. Such a heavy-handed measure was designed not only to instill fear among the smugglers active between the island of Kastellorizo and the Turkish coast but also to make a statement to the Italians, who had thus far turned a blind eye to smuggling from the Dodecanese Islands they had controlled since 1912.

${ }^{16}$ BCA, 30.18.1.1, 19-30-12, 11 May 1926.

${ }^{17} \mathrm{BCA}, 30.10,180-242-9$, (17 August 1926), 2; (12 August 1926), 6.

${ }^{18}$ BCA, 30-10, 180-242-8, 9 June 1926, 2.

${ }^{19}$ BCA, 30.10, 51-336-6, 7 May 1928, 4.
} 
side of the border to the next along the entire southern border with Syria," smuggling various items and endangering "our homeland's political security."

The onset of the Great Depression, however, would radically change the nature and extent of smuggling in the Turkish-Syrian borderlands, building upon and in various ways expanding the existing networks of illegal exchange that had thus far thrived by smuggling goods produced by the state monopoly. From 1929 onward, when trade restrictions began under the economic urgencies brought about by the Great Depression, widening tariff discrepancies coupled with import quotas introduced to limit exports would start feeding into illicit circuits new commodities that previously had been legally exchanged. As a result, the introduction of protectionist tariffs in the late 1920s would gradually turn Turkey into "the happy hunting ground of smugglers." ${ }^{21}$ On Turkey's southern border with Syria in particular, the changing parameters of global trade would soon offer a range of opportunities to the growing class of unemployed who were ready to navigate newly open avenues of illicit exchange. ${ }^{22}$

\section{The Great Depression and the Path to Protectionism}

On 28 November 1931 İsmet İnönü, the Turkish prime minister, sat in front of the telegraph machine and asked Şükrü Kaya, his minister of interior, whether he had any specific insights into the prevention of smuggling, given his recent contacts in the Turkish-Syrian borderlands. "Particularly since the recent introduction of new measures [of import quotas]," İnönü reminded him, "smuggling has resurfaced all the more strongly." Pointing out the heated debates in the parliament that day, he said he expected an immediate answer, but Kaya responded that he could only respond at length few days later, frustrating his prime minister's hopes for a quick fix. ${ }^{23}$

Since the fall of 1929, Turkish politicians, including İnönü, had lost all optimism regarding the national economic recovery they had once dreamed of. ${ }^{24}$ Prior to August 1929, unaware of the impending economic slowdown, they had cultivated high hopes, particularly because tariff restrictions imposed on Turkey by the 1923 Treaty of Lausanne were set to expire. ${ }^{25}$ Although the signatories of the treaty formally recognized a politically independent Turkey, they had managed to retain favorable customs rates by pressing for the continued implementation of the 1916 Ottoman customs tariff for the next five years, during which time Turkey could neither impose new tariffs nor establish import quotas. ${ }^{26}$ "Required to follow the liberal agenda agreed upon in international treaties," as Reşat Kasaba noted, Turkey would only become "fully independent" in the 1930s, when it could set its own commercial and monetary policy without any foreign tutelage or restrictions for the very first time. ${ }^{27}$

Yet a series of interrelated events in 1929 unraveled the hopes for economic independence in unexpected ways. The prospect of instituting new tariffs that had kept the politicians in Ankara hopeful for an increase in public revenues actually led to skyrocketing imports, as many sought to preempt the new tariffs by stockpiling goods. Istanbul's ports struggled to cope with a 20 percent increase in imports, lacking sufficient warehouses and necessary equipment to haul cargoes. ${ }^{28}$ By the end of 1929, higher import volumes depleted Turkey's foreign currency reserves and devalued the lira radically, in line with the currency's long-term devaluation since $1926 .{ }^{29}$ Speculation and economic panic only made

\footnotetext{
${ }^{20}$ Centre des Archives Diplomatiques de Nantes (hereafter CADN), Fonds Beyrouth, Services Spéciaux, 1SL/1/V, 2145, Contrebande, Déserteurs Turcs et Syriens, 1934-1944, “Contrebande," 26 December 1926. BCA, 30.10, 262-766-27, 23 April 1927, 2.

21“Turkey Tackles Smuggling Evil,” New York Times, 24 January 1932, 4.

${ }^{22}$ BCA, 30.10, 179-238-10, 8 August 1933, 5.

${ }^{23}$ BCA, 30.10, 180-244-5, 28 November 1931, 1-2.

${ }^{24}$ İlhan Tekeli and Selim İlkin, 1929 Dünya Buhranında Türkiye’nin İktisadi Politika Arayışları (Istanbul: Bilge, Kültür, Sanat, 2009) 75 .

${ }^{25}$ Şevket Pamuk, “Turkey: 1918-1945," in A History of Middle East Economies in the Twentieth Century, ed. Roger Owen and Sevket Pamuk (Cambridge, MA: Harvard University Press, 1998), 10-29.

${ }^{26}$ Çağlar Keyder, The Definition of a Peripheral Economy: Turkey 1923-1929 (Cambridge, UK: Cambridge University Press, 1981), 69-71; Dilek Barlas, Etatism and Diplomacy: Economic and Foreign Policy Strategies in an Uncertain World, 1929-1939 (Leiden: Brill, 1998), 80-81.

${ }^{27}$ Reşat Kasaba, "Hard Times in Turkey," New Perspectives on Turkey 23, no. 1-4 (2000): 1-4.

28“Antrepo Buhranı," Aksam, 8 June 1929, 3.

${ }^{29}$ Bilsay Kuruç, Belgelerle Türkiye İktisat Politikası, vol. 1, 1929-1932 (Ankara: Ankara Üniversitesi Basımevi, 1988 ), 41.
} 
the situation worse because the public at large, "inconsiderate of how this could damage the national economy," as the prime minister put it, began to seek foreign currencies to exchange with liras. ${ }^{30}$ Such a rhetorical outburst in Ankara was understandable, as the establishment lacked institutions such as a national central bank that could have acted under these circumstances to stabilize currency. ${ }^{31}$

Collapse of the global demand for agricultural foodstuffs only exacerbated these problems, since the export of cash crops such as cotton, raisins, figs, hazelnuts, and tobacco was the major source of foreign currency, much needed to repay Turkey's standing debt. ${ }^{32}$ To compensate for their losses, producers increased their agricultural output, but the growth in supply only drove prices lower, such that they made less despite selling more. In fact, producers were not even able to cover the initial costs of production and transportation, significantly diminishing their ability to honor their financial commitments. ${ }^{33}$ The situation was so far-reaching that the Kemalist government in Ankara, a single party regime until then, even experimented, albeit briefly, with the establishment of a new political party to give vent to the frustrations of the disgruntled. ${ }^{34}$ Campaigning on a platform of liberal economic principles, the new party quickly attracted unexpected electoral support and was shut down by the regime in November 1930 only three months after its inception. The politicians in Ankara, once again united and safe from factionalism, began to speak the same language: the necessity to introduce high tariffs, import quotas, and a tight regime of foreign currencies, with local consumption to safeguard domestic industries and create a self-sufficient national economy. ${ }^{35}$

To be sure, the transformation of Turkey's economy toward more protectionism mirrored global trends, notably the Smoot-Hawley Tariff Act of 1930 in the United States. Neighboring Syria, on the other hand, then under the French mandate, lacked the national sovereignty to react in kind. ${ }^{36}$ As Geoffrey D. Schad put it, the introduction of protectionist tariffs in Syria was more "glacial and the mechanism of tariff reform cumbersome." ${ }^{37}$ After all, unlike Turkey and Egypt, which had to follow the liberal economic agenda only for a fixed term of five years, Syria was actually bound by the arrangements of the League of Nations to stick to an open-door policy with low tariffs for the duration of the French mandate. ${ }^{38}$

Therefore, as Turkey increased tariffs, the widening tariff differences with French Syria made smuggling all the more lucrative. However, the growing profitability of illegal exchange applied less to goods produced locally in Syria, which carried only small profit margins for those involved in illicit transactions. It was instead goods imported into Syria with low tariffs that promised greater returns when smuggled into Turkey. ${ }^{39}$ This was particularly true for Japanese textiles, which were subject to increasingly heavy tariffs once they reached Turkey. The cotton and silk textiles that Japan dumped in French Syria were re-exported by smugglers into Turkey. ${ }^{40}$ Similar to the explosion of silk textile smuggling from Uruguay and Brazil into Argentina in the early 1930s, the widening tariff differences made the smuggling of these textiles from Syria into Turkey an extremely lucrative business. ${ }^{41}$

\footnotetext{
${ }^{30}$ Türkiye Büyük Millet Meclisi (TBMM) Zabıt Ceridesi, vol. 13, 13. İnikat, 12 December 1929, 31.

${ }^{31}$ Çağlar Keyder, State and Class in Turkey: A Study in Capitalist Development (London: Verso, 1987), 97.

${ }^{32}$ Barlas, Etatism, 81.

${ }^{33} \mathrm{BCA}, 30.10,26-152-10,17$.

${ }^{34}$ Cem Emrence, "Politics of Discontent in the Midst of the Great Depression: The Free Republican Party of Turkey (1930)," New Perspectives on Turkey 23, no. 1-4 (2000): 31-52.

${ }^{35}$ Yiğit Akın, "Umutlar, Korkular, Kaygılar: Dünya Iktisadi Buhranının Siyasal Düşünce Ortamına Etkileri," Modern Türkiye'de Siyasi Düşünce, vol 9: Dönemler ve Zihniyetler (Istanbul: Iletişim Yayınları, 2009), 339-40.

${ }^{36}$ For earlier tariffs between Turkey and French Syria, see Norman Burns, The Tariff of Syria, 1919-1932 (Beirut: American Press, 1933), 52-66.

${ }^{37}$ Geoffrey D. Schad, "Colonialists, Industrialists, and Politicians: The Political Economy of Industrialization in Syria, 19201954," (PhD diss., University of Pennsylvania, 2001), 152.

${ }^{38}$ In Egypt, the lower tariffs were fixed at 8 percent ad valorem and expired on 16 February 1930 (Middle East Centre Archive, St. Anthony's College, Oxford [hereafter MECA], Eden Tatton-Brown Collection GB 165-0433, 5 Memoirs, 43). Turkey's tariffs expired on 6 August 1929 (BCA, 30.10, 179-238-10, 8 August 1933, 11). Cyrus Schayegh, The Middle East and the Making of the Modern World (Cambridge, MA: Harvard University Press, 2017), 164.

39“"Múahada Tijariyya bayna Suriyya wa Turkiyya, al-Bida’í al-Muharaba Tubaú bi-Athmana Mubkhasa," al-Qabas, 30 December 1931, 2; Frank Peter, Les entrepreneurs de Damas: Nation, impérialisme et industrialisation (Paris: L'Harmattan, 2010), 206.

${ }^{40}$ BCA, 30.10, 180-244-6, 5 December 1931, 6.

41"Wars on Silk Smugglers," New York Times, 15 October 1930, 14.
} 
Japanese textiles were initially unknown in the Middle East, since Japanese engagement with the region's markets before 1929 was largely limited to its attempts to establish reliable credit networks, introduce cost-efficient shipping lines, and carry out promotional events that sought to improve the brand recognition of Japanese products. ${ }^{42}$ By the early 1930s, however, the introduction of protectionist measures, particularly in Japan's major export markets such as China and India, made the Japanese much more aggressive in their quest for market shares in places like the Middle East and Africa. ${ }^{43}$ This was particularly the case in places like Syria, where France maintained lower tariffs to facilitate its own penetration of Syrian market. ${ }^{44}$ Poised to take advantage of liberal tariff regimes, Japanese companies began to cater to a sturdy local demand for cheap textiles and quickly replaced traditional suppliers like Britain and Italy. ${ }^{45}$

In late 1931, when Japan departed from gold standard and depreciated the yen, the costs of its textiles dropped further, leaving other global manufacturers entirely unable to compete. ${ }^{46}$ Amid accusations of dumping, Japan became the focal point of popular protests and labor strikes centering around Aleppo where "a joint front of patrons and workers" asked for tariff increases, if not outright prohibitions of Japanese imports. ${ }^{47}$ Upper-class women in Aleppo, led by the wives and daughters of the nationalist politicians, joined in by calling for a boycott of European goods and consumption of local textiles only. ${ }^{48}$ Combined with appeals from local industrialists for a more proactive tariff policy, these demands bore only partial fruit in $1932 .{ }^{49}$ The French tariff policy continued to remain largely piecemeal and uncertain in the face of Japanese competition; France itself feared possible retaliation in Indochina, where Japan suffered from a heavy trade deficit due to its substantial rice imports. These French imperial constraints paved the way for a nondiscriminatory tariff policy for Japanese textiles throughout the 1930s. ${ }^{50}$

Unlike the French in Syria, a less constrained Turkey not only increased tariff barriers in 1929 but also introduced import quotas in 1931 that could hurt Japan "more seriously than any other country." 51 Followed by the introduction of clearing agreements in 1932, these measures radically undercut Japanese textiles in Turkey's formal economy. Yet Turkey's porous border with Syria meant that Japanese textiles, in addition to the ones locally manufactured in Aleppo, were now smuggled on a large scale. In major provincial cities close to the Syrian border such as Siirt, Diyarbakır, Mardin, and Urfa merchants openly complained to the Turkish minister of interior that they had not been able to sell even a meter of domestically produced silk textiles since 1929. Neither Turkish manufacturers of cotton cloth in Izmir and Adana nor the silk textiles of Bursa and Istanbul were able to compete with the prices of Japanese textiles, which threatened to destroy local production. ${ }^{52}$ For example, Diyarbakır, a city close to the southern border, had traditionally boasted small-scale production of silk scarfs and long veils that catered to a limited interregional market. By 1931, however, "this demand suddenly came to a halt because of the smuggling from Syria of Western textiles made out of artificial silk," eventually forcing

\footnotetext{
${ }^{42}$ Hiroshi Shimizu, "Rise and Fall of Japan as a Principal Supplier of Cotton Manufactures for Turkey: The Inter-War Period," Middle Eastern Studies 21 no. 1 (1985): 15-32; Nobuo Misawa, Turk Japon Ticaret Iliskileri (Istanbul: ITO Ekonomik ve Sosyal Tarih Yayınları, 2010), 106-39.

${ }^{43}$ John Sharkey, "British Perceptions of Japanese Economic Development in the 1920s: With Special Reference to the Cotton Industry," in The History of Anglo-Japanese Relations, 1600-2000, vol. 4, Economic and Business Relations, ed. Janet E. Hunter and S. Sugiyama (New York: Palgrave, 2002), 264-69.

${ }^{44}$ Philip Shukry Khoury, Syria and the French Mandate: The Politics of Arab Nationalism, 1920-1945 (Princeton, NJ: Princeton University Press, 1987), 91.

${ }^{45}$ H. E. Satow, Report on the Trade, Industry and Finance of Syria, 1923 (London: Majesty's Stationery Office, 1923 ), 7.

${ }^{46}$ Joseph Sassoon, Economic Policy in Iraq, 1932-1950 (New York: Frank Cass, 2006), 216-18.

${ }^{47}$ Geoffrey D. Schad, "Toward an Analysis of Class Formation in Syria: Aleppo's Textile Industrialists and the Workers during the Mandate," in France, Syrie et Liban, 1918-1946: Les ambiguïtés et les dynamiques de la relation mandataire, ed. Nadine Meouchy (Damascus: Presses de l'Ifpo, 2002), 227.

${ }^{48} \mathrm{CADN}$, Fonds Beyrouth, 1SL/1/V/956, Sureté Générale, "Réunion des dames musulmanes extrémistes," Alep, 27 February 1932.

${ }^{49}$ Noureddine Bouchair, "The Merchant and Moneylending Class of Syria under the French Mandate, 1920-1946" (PhD diss., Georgetown University, 1986), 90-93.

${ }^{50}$ Hiroshi Shimizu, “The Mandatory Power and Japan's Trade Expansion into Syria in the Inter-War Period," Middle Eastern Studies 21 no. 2 (1985): 152-71.

${ }^{51}$ National Archives (hereafter TNA), FO 424-539, “Annual Turkey Report for the Year 1931,” 12.

${ }^{52}$ BCA, 30.10, 180-244-6, 5 December 1931, 6.
} 
producers in Diyarbakır to cut down their mulberry trees and start growing vegetables in their stead. ${ }^{53}$ The situation was no different in Bursa, a major center of textile production in western Turkey, where the sales dropped dramatically, leaving producers unable even to cover the costs of initial production. ${ }^{54}$ İbrahim Zühtü Bey, the owner of a silk cloth factory in the city, complained that too many factories competed in a narrowing market, and none of these domestic producers could compete with the smuggling of cheap silk textiles across Turkey's southern borders. He added, "even the French factories could not." 55

\section{Illicit Circuits: South to North}

"In an agreeable weather, smuggling does not even need human labor around here," wrote the journalist Mumtaz Faik in 1937. "When the southern winds pick up pace, it might even be possible for cigarette papers and silk textiles, if placed carefully on one side of a path on the other side, just to fly over across the border." ${ }^{56}$ Even when borders were attractively porous, however, smuggling still required human labor. The latter was abundant after the Great Depression, which swelled the ranks of the growing class of unemployed on both sides of the national borders. In Syria, for example, many local manufacturers of handicrafts who could not compete with the dumping of foreign textiles went out of business by the early 1930s. ${ }^{57}$ The Damascus Chamber of Commerce put the number of those affected from the collapse of handicrafts alone at 77,000. ${ }^{58}$ In rural areas hit by drought and low agricultural prices, the situation was no better. Many rural residents began to migrate to urban areas, filling the ranks of the urban poor in both Syria and Iraq. ${ }^{59}$

Those located in northern Syria first sought solutions elsewhere. Starting in the summer of 1928, they increasingly began to cross into Turkey, heading to the environs of Mersin and Adana-provinces that traditionally held good prospects for seasonal labor. ${ }^{60}$ At a time when Turkey itself was suffering from drought and a downturn in the agricultural sector, however, the increasing presence of Syrians quickly prompted Ankara to start denying visas to these incoming laborers. ${ }^{61}$ Barred from the formal economy, this growing class of itinerant unemployed gradually turned toward more risky but lucrative illegal ventures in a bid for survival. ${ }^{62}$ "Profits from illicit trade," the French authorities concluded, "were too high not to tempt a population deprived of any other means of subsistence." ${ }^{63}$ As one destitute smuggler explained to the journalist Yaşar Kemal, smuggling could make them rich in a matter of just a year or two. ${ }^{64}$ It was such dreams of quick access to wealth that would continue to motivate unlawful pursuits in one generation after another.

Yet the desire to make a profit did not make one smuggle alone, for illicit cross-border circuits developed out of complex networks based on trust that were time-hardened by a long history of personal connections and overlapping commercial interests. After all, smuggling required one to navigate a strong network of intermediaries that included shop owners, smugglers, trackers, border agents, cross-border

\footnotetext{
${ }^{53}$ Basri Konyar, Diyarbekir Yıllı̆̆ı, vol. 3 (Ankara: Ulus Basımevi, 1936), 109.

54"İpekçilikte Buhran," Cumhuriyet, 29 September 1931, 1, 4.

55“"Bursa'nın Büyük Derdi," Cumhuriyet, 25 October 1931, 6.

${ }^{56}$ Faik, "Cenup Hududu." The Turkish-Syrian border was a crucial point of reference in the public debate over national security and economic independence throughout the 1930s. This was particularly the case in 1937 during the lead-up to the crisis over the Syrian Sanjak of Alexandretta, when Turkish national newspapers began to solicit columns from journalists who began to report at length on the border with Syria. Mümtaz Faik (Fenik), then a young journalist and later a deputy for the Democrat Party, published more than fifty columns on the Turkish-Syrian border in the national daily Tan. His column stirred interest on both the national and local levels, even sparking a debate with a local newspaper from Mardin, Ulus Sesi, that challenged some of Faik's assumptions. See "Mümtaz Faiktan: Mardin ve Cenub Bolgesi Hakkında," in Ulus Sesi, 22 January 1937, pg. 1-2; “Mümtaz Faiktan: Mardin ve Cenub Bolgesi Hakkinda II,” in Ulus Sesi, 23 January 1937, pg. 2.

${ }^{57}$ Shimizu, "Mandatory Power," 156.

${ }^{58}$ Khoury, Syria and the French Mandate, 397.

${ }^{59}$ Peter Sluglett, Britain in Iraq: Contriving King and Country (London: I. B. Tauris, 2007), 136.

${ }^{60}$ BCA, 30.10, 180-242-10, 2 September 1926, 1.

${ }^{61}$ BCA, 30.10, 206-406-17, 18 November 1928, 1. On drought, see Necmettin Sadik, "Birinci Is," Aksam, 30 May 1929.

${ }^{62}$ Elif Akçetin, “Anatolian Peasants in the Great Depression, 1929-1933," New Perspectives on Turkey 23, no.1-4 (2000): 79-102, 89.

${ }^{63}$ CADN, Fonds Beyrouth, Services Spéciaux, 1SL/1/V, 2145, “D’Alep a Damas,” no. 401/98, 6 February 1932, 3.

${ }^{64}$ Yaşar Kemal, Nuhun Gemisi: Bu Diyar Baştanbaşa 1 (Istanbul: Yapı Kredi Yayınları, [1971] 2004), 69.
} 
hosts, and peddlers - a coalition that deeply bothered Turkish authorities. ${ }^{65}$ This coalition constituted a moral economy in ways similar to the paternalistic economy of provisions in England or the peasant economies of Southeast Asia. ${ }^{66}$

Operating in an uncertain world susceptible to informants, smugglers also placed great significance on interpersonal trust, idealized notions of reciprocity, and a shared sense of socioeconomic justice. Their illicit conduct was characterized by informal credit relations that avoided formalized capitalist procedures. Creditworthiness in the Turkish-Syrian borderlands was primarily dependent on elaborate networks of trust that enabled all parties to share risks equally. For instance, the shop owners who worked with smugglers and thereby risked legal prosecution sold their goods at a higher rate than the market value in Syria. Yet the difference from the market prices they charged was put on credit and payable only if the goods made it across the border without being confiscated by the Turkish authorities en route. "With such calculus," the Turkish authorities noted, "the risks are minimized not only for the merchants who work with smugglers, but also for the latter who actually cross the border." ${ }^{67}$ In this context, the shop owners who had enough capital to provide credit to smugglers actually prospered in the long run. Melki Esmer was one such merchant with sufficient capital resources, running a large warehouse in the border town of Qamishli. An Armenian, formerly Ottoman, Esmer specialized in silk and cotton cloths, particularly calico (patiska), and he was known for providing ample credit. Strak of Hasankeyf was another merchant in Qamishli who specialized in the sale of marocain fabric. Despite having more limited capital, he provided easy loans as well. ${ }^{68}$

The ready availability of credit did not mean, however, that it was available to everyone; rather it was given only to those who cultivated a fair degree of what one might call "market reputation." This was determined by one's origins and the number of transactions successfully concluded, and augmented by stories that highlighted courage and resilience. Smugglers actively participated in this process by recounting stories and thereby marketing themselves, contributing to a robust genre of generic smuggling adventures that constantly circulated in the borderlands. "The narratives are plenty," noted Yaşar Kemal. "Choose one of the generic accounts and simply tailor it to yourself. The smugglers of Antep are working for us," manufacturing story lines. ${ }^{69}$

This world of assurances was not filled only with fiction, however. After all, smugglers needed a reputation bolstered by the solid references of those who could vouch for their reliability and integrity of character. They were often found among the closely knit circle of friends, compatriots, and relatives who could provide the simplest of assurances: that "he is one of us." ${ }^{70}$ Just like smugglers, merchants also needed market reputation. Antuvan the Tailor, an Ottoman Assyrian who hailed from Diyarbakır, set up a drapery business in Qamishli. Together with his two brothers, one located in Aleppo and the other in Ras al-Ayn, Antuvan thrived on great market credibility that enabled him to deliver textiles at different drop-off locations along the border. ${ }^{71}$

Those engaged in unlawful transactions not only cultivated networks of trust and built solid reputations but also were equipped with the necessary fluidity of borderland cultures that allowed them to navigate constantly shifting identities under complex circumstances. ${ }^{72}$ One smuggler noted that he had both Syrian and Turkish citizenship and said, pointing to the border, that "you put on Turkish clothes here, Arab clothes over there; that is the way to do it." ${ }^{73}$ Another similarly remarked that he hailed from the

\footnotetext{
65“Filik Terkiy 'ala al-Hudud, M'araka fi al-Jazirah al'Uliya m’a Muharabin,” al-Kabas, 1 February 1932, 2.

${ }^{66}$ E. P. Thompson, "The Moral Economy of the English Crowd in the Eighteenth Century," Past \& Present 50 (February 1971): 76-136; James C. Scott, The Moral Economy of the Peasant: Rebellion and Subsistence in Southeast Asia (New Haven, CT: Yale University Press, 1976) 167-69.

${ }^{67}$ BCA, 30.10, 180-244-6, 5 December 1931, 7.

${ }^{68}$ Mümtaz Faik, "Kaçakçı Aynı Zamanda bir Casustur," Tan, 12 January 1937, 2.

${ }^{69}$ Yaşar Kemal, Nuhun Gemisi, 64.

${ }^{70}$ Ibid., 58.

${ }^{71}$ Mümtaz Faik, "Kaçakçı Aynı Zamanda."

${ }^{72}$ Thomas M. Wilson and Hastings Donnan, "Nation, State and Identity at International Borders," in Border Identities: Nation and State at International Frontiers, ed. Wilson and Donnan (Cambridge, UK: Cambridge University Press, 1998), 12-13.

${ }^{73}$ Yaşar Kemal, Nuhun Gemisi, 53.
} 
village right across the border, where his uncle still lives. "Once we cross the border into our village, we will don Arab clothes" to ward off unwanted attention. ${ }^{74}$

Family and tribal ties were indeed prominent safety networks for pursuing illicit conduct. Many smugglers who crossed into Turkey operated out of places where they had relatives. Selling smuggled textiles was particularly tricky, after all: unlike sugar or salt, which could be easily blended into the existing licit stocks, silk or cotton textiles were more easily discovered by authorities; someone would need to sell them under the table. ${ }^{75}$ This was often done through bohçacl-the itinerant female peddlers of clothes who served as perfect intermediaries by navigating female-only domestic zones from one house to the next, or from weddings to Sufi lodges. ${ }^{76}$ Just as the fashionable Western clothes that came from Aleppo dictated the parameters of fashion for the elite women in the borderlands, the textiles bohçacıs sold catered to local tastes.

Although textiles played a major role in illegal cross-border exchanges beginning in 1929, they were not the only commodity trafficked from Syria into Turkey. Coalitions also engaged in smuggling large quantities of goods that were subject to state monopoly production and sale. These goods ranged from cigarette paper to salt, alcohol, gas, sugar, coffee, matches, and lighters, diversifying the cargoes of smugglers. "In the past two to three years," a report woefully concluded by late 1931, "there was nearly no sugar and gas that got shipped to the towns bordering Syria with duties paid." alence of illicit flows, Turkey began experimenting with price-fixing mechanisms for key commodities beginning in the mid-1920s. Turkey, for example, with its tobacco monopoly, could boast that it offered the cheapest cigarette to its consumers, seeking to undercut tobacco smuggling. ${ }^{78}$ A similar policy was applied to salt and raki (an anise-flavored alcoholic drink); the state kept the prices low in the borderland communities. ${ }^{79}$ Yet the state could not target textiles with a price-fixing mechanism, which continued to be the most frequently smuggled commodity. In the end, silk and cotton clothes offered the highest profit margin to the smugglers and at the same time were the most damaging to the state treasury due to the heavy customs duties they carried. Hopes for quick profits from their trade even attracted smugglers from faraway regions, who began to run convoys with armed guards, as large as fifty men strong. ${ }^{80}$

Many hamlets that dotted the border featuring no more than a handful of huts before the late 1920s slowly began to grow in response to this fertile illicit economy. As hamlets gradually turned into villages and towns into small cities, with the opening of many shops and depots border communities gradually turned into commercial centers that drew merchants from western Syria who hoped for quick profits from illegal cross-border exchanges. ${ }^{81}$ According to one possibly exaggerated calculation, there were around forty-four market towns in Syria along the Turkish border from Payas to Cizre, featuring a total of 1,765 shops and stores. ${ }^{82}$ Darbasiya was one such town that the border divided into two. On the Syrian side, the town had a population of 2,500, with an Assyrian majority. Disproportionate to the population of this small town, there were fifty drapers who traded silk and cotton textiles, as well as eighty-one aktar shops, a type of a general store. ${ }^{83}$ Amuda was another border town that had a population of just 3,625 but was serviced by no less than 150 aktar shops, which were, according to the journalist Mümtaz Faik, fronts for trafficking silk and cotton textiles across the border. ${ }^{84}$ Perhaps the most striking example was the hamlet of Àyn Diwar that was ceded "with its three roofed structures" to the French in June 1930 as part of the border settlement. In a matter of two years, the Turkish authorities sighed, Ain Divar had grown into a village of 200 houses and eighty stores. ${ }^{85}$ The story was the same for

\footnotetext{
${ }^{74}$ Ibid.

${ }^{75}$ BCA, 30.10, 180-244-6, 5 December 1931, 9.

${ }^{76}$ Yaşar Kemal, Nuhun Gemisi, 57-58.

${ }^{77}$ BCA, 30.10, 180-244-6, 5 December 1931, 3.

${ }^{78}$ BCA, 30.10, 179-238-10, 8 August 1933, 21-25.

${ }^{79} \mathrm{BCA}, 30.10,180-244-6,5$ December 1931, 6.

${ }^{80}$ Ibid., 4, 15.

${ }^{81}$ Christian Velud, "L'emergence et l'organisation sociale des petites villes de Jezireh, en Syrie, sous le mandat français," URBAMA 16-17 (1986): 85-103, 94.

${ }^{82}$ Mümtaz Faik, "Hudut Boyundaki Bütün Pazarların Umumi Bir Tablosu," Tan, 17 January 1937, 2.

${ }^{83}$ Mümtaz Faik, "Derbesiye’nin Yarısı Bizde, Yarısı da Suriye Dahilindedir," Tan, 16 January 1937, 2.

${ }^{84}$ Mümtaz Faik, "Bir Kaçak Merkezi Daha: Amude," Tan, 13 Ocak 1937, 2.

${ }^{85}$ BCA 30.10, 180-244-6, 5 December 1931, 2; TNA, FO 371/16975/E1144, 28 February 1933, 242.
} 
more prominent towns such as Qamishli, which was established by the French in 1926 but became the most important commercial center in the region by $1929 .^{86}$

"Tolerated and even encouraged" by the French, smuggling had become the engine of regional economic growth and urban expansion along the Turkish border. ${ }^{87}$ Yet the question of the number of shops and size of border villages that took part in illicit trade remained hotly contested. The Turkish authorities tended to exaggerate the scale and number of those involved, whereas the French sources chose to play them down. ${ }^{88}$ Both publicly and in private, Ankara pointed fingers at French officials time and again, accusing them of protecting smugglers and having a vested interest in increased volumes of illegal trade that gave the borderland communities a new lease on life at the expense of Turkish coffers. In the eyes of Ankara, the French ultimately did very little in the way of enhancing border security, in contrast to Turkey's borders elsewhere, such as the borders with Iran and the Soviet Union, where both sides strove to maintain tight controls and keep smuggling to a minimum. ${ }^{89}$

One British official interpreted continued Turkish frustration with smuggling across its Syrian border as largely a political matter informed by unhappiness with "the French authorities in Syria for settling large bodies of Armenians, Kurds, and Circassians near the Turkish frontier." "90 Ankara indeed continued to file protests to the French over the years, seeking removal of minorities from the sensitive zone where they were accommodated by mandatory authorities. ${ }^{91}$ To be sure, the Turkish authorities also considered illegal economic activity a factor that played into the political agendas of former Ottoman subjects such as Kurds, Armenians, and Assyrians living along the border. ${ }^{92}$ In their private conversations among themselves, however, Turkish authorities were careful not to reduce the complexity of illicit networks to a manifestation of ethno-religious loyalties. The minister of interior Şükrü Kaya noted that border shops catering to the smugglers were owned by a mixture of former Ottoman subjects such as Armenian and Assyrians who knew the languages, trade networks, and market dynamics on both sides of the border. ${ }^{93}$ In a private meeting in which the reasons for the rise in smuggling and border security concerns were extensively discussed, Seyfi Düzgören, the commander general for customs security, put less emphasis on ethnic loyalties than on tariff discrepancies, the geography of the border, French policies, and Ankara's difficulties severing southern Turkey from Aleppo, its historical supply center. ${ }^{94}$

In borderlands that were particularly defined by a multiplicity of ethno-religious identities, smuggling circuits did not follow ethno-religious affiliations neatly. When a piece of intelligence emerged indicating that Kurds were plotting with Armenians to establish a new state, a project presumably supported by a member of the Bedirkhan family, one British official opined that "these reports probably relate to persons engaged in smuggling between Syria and the adjacent Turkish vilayets, who wish to give a more respectable appearance to their activities by engaging in politics." ${ }^{95}$ Ethno-religious loyalties therefore constituted only one of many currencies valid in a smuggling economy that thrived in borderlands - areas that are above all defined by the primacy of complex networks of trust.

\section{Illicit Circuits: North to South}

France was not the only country that encouraged illicit exchange; nor was Japan the only exporter that dumped goods on foreign markets. Turkey itself did both. Illegal circuits did not operate in just one direction after all. Just as the Turkish markets were flooded by cheap Japanese silk and cotton textiles coming

\footnotetext{
${ }^{86}$ TNA, FO 371/16975/E1144, 28 February 1933, 241-42.

${ }^{87}$ Jordi Tejel, Syria's Kurds: History, Politics and Society (London: Routledge, 2009), 67-68.

${ }^{88} \mathrm{CADN}$, Fonds Beyrouth, Services Spéciaux, 1SL/1/V, 2145, "Delegation Francaise à Postes Frontaliers a Azaz, Djerablous, Arab-Pounar," 19 January 1938.

${ }^{89}$ M. Bülent Varlık, ed., Umumi Müfettişler Toplantı Tutanakları (1936) (Ankara: Dipnot Yayınları, 2010), 126.

${ }^{90}$ TNA, FO 371/15381/E6375, December 28, 1931, 391.

${ }^{91} \mathrm{CADN}$, Fonds Beyrouth, Services Spéciaux, 1SL/1/V, 2181, “4 Session Commission Permanente de Frontières," 12 Avril 1943, 2-4.

${ }^{92}$ Benjamin Thomas White, The Emergence of Minorities in the Middle East: The Politics of Community in French Mandate Syria (Edinburgh: Edinburgh University Press, 2011), 113-17.

${ }^{93}$ BCA, 30.10, 180-244-6, 5 December 1931, 2-3.

${ }^{94}$ Varlık, Umumi Müfettişler, 41-46.

${ }^{95}$ TNA, FO 371/16981/E522, 7 January 1933, 53.
} 
from Syria, so did markets in the Middle East become flooded with narcotics smuggled from Turkey beginning in 1929.

Ottoman Anatolia had long been home to poppy fields, where peasants had grown this labor-intensive crop for many centuries using traditional methods in small-scale family-run operations. By the early 1830s, the prospects of an ever-growing Chinese demand for opium coupled with the successes of the British monopoly led the Ottomans to establish a domestic opium monopoly of their own and try to find a niche in the Chinese market. Although Britain eventually contained Ottoman efforts through a liberal trade agreement that outlawed Ottoman monopolies, opium continued to be an important cash crop in the Ottoman Empire, claiming "nearly ten percent of all agricultural exports from Anatolia." 96 By the late 19th century, the growing popularity of opioids such as heroin, which was increasingly used both pharmaceutically and recreationally, raised questions about international regulation of the manufacture and sale of mind-altering substances. Yet such trade limitations were often forced on producer countries by consumer nations at the expense of the former; hence international cooperation was not easily forthcoming.

As a major producer, the Ottoman Empire, and later Turkey, tended to avoid entering into international talks starting at the turn of the century, or embraced an uncompromising attitude when it did so. Bypassing the emerging conventions and norms worked to its own benefit. Thriving in this environment were merchants from Istanbul who argued that "Turkey, not being a party to the Geneva Convention [1925], can export unlimited quantities" of narcotics. ${ }^{97}$ As such international regulations forced the closure of heroin factories in Western Europe, notably in Paris and Basel, the center of production gradually shifted to Istanbul, where three factories established by French and Japanese manufacturers opened their doors to meet the surging global demand. ${ }^{98}$

The timing could not have been better for this burgeoning opioid industry. The Great Depression that had hit cash-crop growing regions the hardest led Turkish peasants to rapidly shift to the cultivation of opium. After a visit to his constituency in May 1930, Tahsin Bey, the parliamentary deputy for Denizli, confessed that he "had never seen opium poppies in the environs of Denizli and Aydın for the past thirty years, but now they covered all the fields stretching from Balıkesir to Denizli." Replacing crops such as tobacco, barley, and corn, opium became the only profitable product for the peasants in 1929. Costs of cultivation and transportation were easily covered because it was light in bulk but high in value.99

Turkey therefore emerged from the Great Depression as a major cultivator of raw opium, with ready industrial facilities in a port city that processed high-quality heroin and morphine destined for consumer societies. ${ }^{100}$ One destination was Egypt, which had emerged from the recession in great economic distress. This pushed sectors of its population "to the margins of labor force (and) encouraged many to engage in drug trafficking." 101 The drug trade offered easy profits and minimal risk that made "the temptation to smuggle enormous." 102 Egypt had suffered from a narcotics problem since the turn of the century. Although Britain forbade Greece from supplying hashish to Egypt in 1910, the Levantine producers in Syria and Lebanon soon absorbed the Greek market share. ${ }^{103}$ Starting in 1918, the Egyptian market also began to see a gradual increase in the heroin supply from European manufacturers, fueling a rise in the number of Egypt's addicts to approximately half a million within a decade. ${ }^{104}$ With the

\footnotetext{
${ }^{96}$ İbrahim İhsan Poroy, "Expansion of Opium Production in Turkey and the State Monopoly of 1828-1839," International Journal of Middle East Studies 13, no.2 (1981): 191-211.

${ }^{97}$ Archives of the League of Nations, R3188, 12/19229/3541, Drug Factories in Turkey, "Letter from Triand M. Fufas, Istanbul, to Messrs. Heinrich Oppermann, Hamburg," 7 March 1931, 3.

${ }^{98}$ TNA, FO 424-539, “Annual Report on Turkey for 1929," 32.

${ }^{99}$ TBMM Zabit Ceridesi, vol. 19, 60. İnikat, 18 May 1930, 120.

${ }^{100}$ Russell Pasha, Egyptian Service, 1902-1946 (London: John Murray, 1949), 239.

${ }^{101}$ Mitchell Alan Bacci, "Smugglers and State Builders: Opiate Trafficking and Institutional Development in Interwar Egypt and Turkey" (MA thesis, University of Texas at Austin, 2017), 22.

${ }^{102}$ Liat Kozma, "White Drugs in Interwar Egypt: Decadent Pleasures, Emaciated Fellahin, and the Campaign against Drugs," Comparative Studies of South Asia, Africa and the Middle East 33, no.1 (2013): 89-101.

${ }^{103}$ Cyrus Schayegh, "The Many Worlds of 'Abud Yasin; or, What Narcotics Trafficking in the Interwar Middle East Can Tell Us About Territorialization,” American Historical Review 116, no. 2 (2011): 273-306.

104“Mısır'da Uyuşturucu İlaçlarla Zehirlenme İptilasının Korkunç Hali,” in Türkiye Hilaliahmer Mecmuası, 111 (15 Teşrin-i sani 1930): 180-81.
} 
crackdown in Europe and the emergence of Turkey as the major supplier of opioids by the late 1920s, nearly all heroin and morphine sold in Egypt originated in Anatolia. ${ }^{105}$ Egypt accordingly mounted an international campaign that framed Turkey as an opportunist nation that dumped opioids on foreign markets, threatening the global moral order. ${ }^{106}$

Increasingly upset with its fading image abroad and concerned with the domestic implications, Turkish authorities closely monitored the foreign press and the negative publicity circulating within the League of Nations. The League's effort to solve moral issues like the smuggling of alcohol and narcotics came at a time when Turkey desperately needed to maintain opium as a major cash crop. In February 1931, in an attempt to appease the international community, Ankara decided to introduce tighter regulations on the operation of the three factories in Istanbul, but production continued uninterrupted. ${ }^{107}$ As Turkish opioids continued to feed the global narcotic networks via Marseilles, international pressure mounted further. By late 1931, the United States openly threatened Turkey with legislation that would prohibit the licit purchase of Turkish opium due to its noncompliance with international regulations. This was followed by American lobbying efforts in Ankara. A few days after a personal meeting between the American ambassador and Mustafa Kemal, Turkey relented and decided to comply with international regulations on opium. ${ }^{108}$

The decision to do so bolstered the broader rapprochement of Ankara with Europe that began in July 1932 when it became a member of the League of Nations. ${ }^{109}$ Until then, Turkey was home to a long list of traffickers who supplied opioids to diverse markets in the Eastern Mediterranean and beyond. For example, individuals such as Nissim Calderon and Mikhaili Anapniotis, both based in Istanbul, were prominent figures in the smuggling of narcotics into Egypt and Ethiopia. The Turkish crackdown and the arrests of some traffickers by the Egyptian authorities in 1932 forced some criminal bosses to relocate first to Bulgaria and eventually to China. ${ }^{110}$

In this process, Ankara also pledged to close down the three factories in Istanbul and announced the creation of a state monopoly to oversee opium production and exports. The centralization of production in few major factories meant that Turkey now had a direct stake in the financial success of its state monopoly on opioids and as a result became more eager to dismantle illegal narcotic networks. Increased vigilance on the part of Turkish authorities coupled with the growing cooperation of the international community in dismantling the illicit circuits in the Eastern Mediterranean would gradually force smugglers to find alternatives to the maritime routes, once the preferred method of shipping narcotics from Istanbul to Egypt. ${ }^{111}$

Starting in the early 1930s, opium and its derivatives, and to a lesser extent hashish, began to find their way across the Turkish-Syrian border, supplying the markets to the south with narcotics that featured higher morphine content. ${ }^{12}$ Turkish opioids that fed into these cross-border circuits often originated from small-scale factories and workshops that continued to operate underground, beyond the purview of Turkey's state-run monopoly. ${ }^{113}$ Turkish hashish was often smuggled through these circuits as well. This was particularly the case after 1929, when the French destroyed sizable hashish fields in its mandated territories and Turkish and Greek hashish producers quickly stepped up to fill the regional demand by supplying hashish of superior quality. ${ }^{114}$

\footnotetext{
${ }^{105}$ Bureau Central d'Informations des Narcotics, Rapport Annuel 1930 (Le Caire: Imprimerie Nationale, 1931), 22.

${ }^{106}$ Bacci, "Smugglers and State Builders," 43-50.

${ }^{107}$ BCA, 30.10, 178-230-1, 19 May 1931, 7.

${ }^{108}$ Ryan Gingeras, Heroin, Organized Crime and the Making of Modern Turkey (Oxford, UK: Oxford University Press, 2014 ), 72. ${ }^{109}$ BCA, 30.18.1.2, 32-80-7, 25 December 1932, 1-2.

${ }^{110}$ Alan A. Block, "European Drug Traffic and Traffickers between the Wars: The Policy of Suppression and Its Consequences," Journal of Social History 23, no. 2 (1989): 323.

${ }^{111}$ Philippe Chassagne, "Opiacés et routes des Balkans: Facteurs géographiques, historiques et politiques du phénomène," Hérodote 112, no. 1 (2004): 139-56, 149.

${ }^{112}$ Central Narcotics Intelligence Bureau, Annual Report for the Year 1938 (Cairo: Government Press, 1939 ), 89.

${ }^{113} \mathrm{CADN}$, Ankara Ambassade, 36PO/1, 323, "Rapport sur le Trafic Clandestin des Stupéfiants en Provenance de Turquie," 10 Septembre 1932, 3.

${ }^{114} \mathrm{CADN}$, Ankara Ambassade, 36PO/1, 323, "Rôle de la Turquie dans la contrebande des stupéfiants au Levant," 2 Mars 1934, $1-2$.
} 
The French authorities were quick to react, blaming Turkey "for spreading its dangerous products towards the south of its territory." 115 First amassed in towns like Adana, Antep, or Kilis, all close to the Syrian border, the narcotics were then smuggled into Aleppo. An unnamed smuggler, in one instance, was known to collect opium from places as far as Bursa and stockpile approximately five tons per year in his private depots in Antep before shipping them to Aleppo. ${ }^{116}$ Aleppo played a central role in illicit narcotic trade. Available French statistics show that drug smuggling across the Turkish-Syrian border was largely restricted to the province of Aleppo, suggesting that drug smuggling was probably monopolized by a few powerful figures in the city. ${ }^{117}$ These Aleppine intermediaries would then tap into existing illegal circuits of hashish traffickers farther south, who trafficked narcotics to Egypt either through the port of Beirut or by the land route crossing British Palestine. ${ }^{118}$

Individuals such as Àbdu Husnu from Antakya were couriers in this trade. He would first cross into Turkey and sell his batch of smuggled textiles in Adana; he would in turn receive a package of hashish originating from Istanbul and traffic it to Aleppo or Beirut, from where it was destined for Egypt. ${ }^{119}$ Although there were not many drug smugglers arrested while operating on this route, the information derived from those who were caught suggested that it was the most common itinerary among smugglers by the early 1940s. ${ }^{120}$ One intercepted shipment in 1935 involved 188 kilograms of Turkish hashish that followed the well-trodden route from Gaziantep to Aleppo, then down south to Beirut and Haifa. Drug smugglers like 'Abbud Yasin thrived in this environment, where surveillance of porous border zones was further challenged by an ever-expanding infrastructure of motorized transportation. ${ }^{121}$

Such transportation links better connected the Turkish producers to illicit distributors via Aleppo, making the fight against drug trafficking more difficult. In one instance in 1933, the authorities at the Adana train station discovered 13 kilograms of cocaine hidden inside a package of textiles and arrested Ahmad Nayali, an Aleppo egg merchant. In this particular circuit, Nayali functioned as a liaison between the Turkish traffickers and a certain Muhammad Shakir, a merchant and distributor of cocaine and hashish in Baghdad. After his arrest, Nayali admitted that it was the fifteenth package he had helped smuggle across the border. ${ }^{122}$ Official figures were therefore far from capturing the real scale of illicit trade, since they only reported the narcotics successfully seized by the authorities. ${ }^{123}$ After all, borders could harden and measures become tighter, but smugglers continued to develop creative methods of their own to avoid capture.

\section{Making a Border: Discourses, Institutions, and Practices}

As one Turkish official put it, the post-1929 period had already led to an explosion in illegal trade, but "the latest addition of narcotics" destroyed not only "state revenues but also threatened national consciousness and identity." 24 It was through the deployment of such discursive frames that Turkey would start trying to halt illicit crossings of its southern border. Narcotics were not the only commodity that presented dangers to the Turkish body politic, however. Speaking in December 1929, Turkish prime minister İsmet İnönü declared that "we will not agree to let our Turkish daughters turn fragile with rotten lungs, while incensed in lavender and donning fine silk cloth." Referring to the nation's historic sacrifices, he reminded his audience of how "their mothers put wildflowers around their heads and carried ammunition to the front thanks to their sturdy bodies." The daughters of the republic should follow suit by

\footnotetext{
${ }^{115}$ Ibid., 3.

${ }^{116}$ Yaşar Kemal, Nuhun Gemisi, 96.

${ }^{117}$ CADN, Fonds Beyrouth, Services Spéciaux, 1SL/1/V, 2145, Contrebande, Déserteurs Turcs et Syriens, 1934-1944.

${ }^{118}$ Gingeras, Heroin, 100-02.

${ }^{119}$ BCA, 30.10, 180-246-3, 12 August 1940, 35.

${ }^{120}$ Bureau Central d'Informations des Narcotics, Rapport Annuel 1944 (Le Caire: Imprimerie Nationale, 1945$), 11$.

${ }^{121}$ Schayegh, "Many Worlds," 273.

${ }^{122}$ CADN, Ankara Ambassade, 36PO/1, 323, "Lettre N 1301 adressée à Monsieur le Chef du Service des Relations Extérieures du Haut-Commissariat," 1 Novembre 1933.

${ }^{123}$ In 1938, for instance, Ankara reported that it managed to shut down twenty-six factories and workshops operating in Turkey and intercepted a total of 11,788 kilograms of narcotics in the course of eight years (BCA, 490.1, 1455-38-1, July 1938, 40).

${ }^{124}$ BCA, 490.1, 1455-38-1, July 1938, 39.
} 
"having a strong physique, putting on domestic silk textiles, wearing the scent of wildflowers, and above all turning their homes into formidable fortresses by being frugal and economical." 125 The establishment in Ankara had good reasons for framing its anti-smuggling campaign in terms of economic warfare, as part and parcel of a continuing struggle for national survival. ${ }^{126}$ By the early 1930 s smuggling cost Turkey around one-tenth of its revenues annually. ${ }^{127}$ Three-fourths of this illegal trade took place across Turkey's southern borders, and one historian concluded that the volume of these illicit exchanges was higher than that of formal transactions between Syria and Turkey. ${ }^{128}$

In analyzing the nature of this trade, government officials often struck a sober tone, sticking to technical analyses of tariffs and price differences. Yet the discourse of economic warfare was a pervasive one. One report, for instance, took as its reference point the Siege of Vienna in 1683, often framed as a symbolic turning point in Ottoman decline, arguing that smuggling carried out by "non-Turkish elements" was one of the reasons the siege had failed. ${ }^{129}$ Such a narrative often roused deep-seated fears of fifth columnists who readily served imperialist ambitions. In the context of the interwar years, the imperialists were the French in Syria, "mobilized in an economic offensive against Turkey," whereas the fifth columnists were the ex-Ottoman Armenians, Assyrians, and Kurds, all situated along the border, where they posed risks with their knowledge of the Turkish interior. ${ }^{130}$ This discourse was reproduced at the direction of Ankara in "a violent press campaign backed up by influential deputies." ${ }^{131}$ Disseminated through local newspapers across southern Turkey, the campaign framed smugglers as the enemies of the nation, responsible for illicit incursions into the motherland. ${ }^{132}$ The newspapers depicted the border as a frontier zone similar to the American West, plagued with prostitution and swarming with criminals, where the richness of Ras al-Âyn resembled that of Chicago and local trackers were comparable to Nat Pinkerton. ${ }^{133}$ In the genre of "dispatches from the wild," these depictions framed the southern border as chaotic and savage in nature, a contrast to the sociopolitical order Ankara sought to represent. ${ }^{134}$

Such cultural constructions of the southern border served to legitimize the impending institutionalization of a more intrusive border regime. Reporting in June 1931, the governor of Cebelibereket (modern Osmaniye) reached the bitter conclusion that catching a smuggler on the border was "a matter of sheer coincidence," and the governor of Antep highlighted the lack of administrative coordination and the susceptibility of border guards to corruption. ${ }^{135}$ By November 1931, a new ministry of customs and monopolies had been established, tasked with creating an effective border regime, and Ankara would spend the rest of the decade introducing uniform militarized border guards together with mechanized units and a better network of informants to support them. ${ }^{136}$ This increased presence of law enforcement along the border was paired with legislation comprising two separate anti-smuggling laws, in 1931 and 1934, that made the trials of those caught conclude faster and the sentences harsher. In Antep alone, the introduction of specialized courts trying only smugglers was said to have reduced illicit transactions by 80 percent from 1932 to 1935 . $^{137}$

This process was by no means peaceful, as it often pit the smugglers and the customs guards against one another. In one such instance in Antep in early January 1934, the government forces intercepted a thirty-person party of smugglers led by Elbistanlı Bekir Dede. After a confrontation lasting two days, they caught twenty-seven smugglers alive, together with their fifty-six bales of contraband from Aleppo. ${ }^{138}$

\footnotetext{
${ }^{125}$ TBMM Zabit Ceridesi, vol. 14, 13. İnikat, 12 December 1929, 33.

${ }^{126}$ Paul N. Hehn, A Low Dishonest Decade: The Great Powers, Eastern Europe and the Economic Origins of World War II, 1930-1941 (New York: Continuum, 2002), 276.

${ }^{127}$ Yunus Nadi, “Niçin Fevkalade Tedbir İstiyoruz?” Cumhuriyet, 21 October 1931, 1.

${ }^{128}$ BCA, 490.1, 1455-38-1, July 1938, 40; Peter, Les Entrepreneurs, 206.

${ }^{129}$ BCA, 490.1, 1455-38-1, July 1938, 41.

${ }^{130}$ Mümtaz Faik, “Fransızlar Türkiye’ye Karşı İktisadi bir Taarruza Geçmişlerdir,” Tan, 9 January 1937.

${ }^{131}$ TNA, FO 424-539, “Annual Turkey Report for the Year 1931,” 10.

132“Kaçakçllara Öğüt: Kaçakçılar Vatana Düşmandır," Yenilik, 30 June 1936, 3.

${ }^{133}$ Mümtaz Faik, “Bir Dağın Yamacına Kenedlenen Mardin,” Tan, 6 January 1937, 2.

${ }^{134}$ Ieva Jusionyte, Savage Frontier: Making News and Security on the Argentine Border (Oakland: University of California Press, 2015), 60.

${ }^{135}$ BCA, 30.10, 180-243-21, 21 June 1931, 3; 12 July 1931, 6.

${ }^{136}$ BCA, 30.10, 179-238-10, 8 August 1933, 5-7.

137 “Gaziantep’te Kaçakçıllk Eskisine Nisbetle \%80 azalmıştır," Ulus Sesi Mardin, 24 January 1935, 3.

${ }^{138}$ TNA, FO 371/17958/E916, 12 January 1934, 322.
} 
"The captured smugglers," one local newspaper reported, were then "paraded through the streets of Antep amidst the execration of the people." ${ }^{139}$ Between 1931 and 1938, the official Turkish records put the number of smugglers who were caught alive at around 40,000, while close to 300 smugglers were killed in these border clashes; the authorities also were able to seize, among many other articles of contraband, more than 40,000 kilograms of silk, 40,000 kilograms of wool, and close to 300,000 kilograms of cotton textiles. Three-fourths of these nationwide figures corresponded to encounters between Turkish customs guards and smugglers along the Turkish-Syrian border. ${ }^{140}$ By 1937, local newspapers reported that many merchants in Aleppo were going out of business and that depots located near the Syrian border were shutting down one after another. ${ }^{141}$ As for the French authorities, it was only the coming of the Second World War and the political risks associated with illegal activities by then, such as the increase in arms smuggling, that would convince them that the presence of only 120 border guards was an unacceptable number, entirely insufficient to monitor the 600 kilometer Turkish border. ${ }^{142}$

\section{Conclusion}

To conclude that the border was finally "fixed" in the course of 1930s, however, would not only be wrong but also a methodological fallacy that buys into the narrative parameters of territorial nation-states. Although the Turkish-Syrian border was certainly more consolidated by the end of the decade, this often meant that illicit circuits across the border began to assume new forms. In this sense, bordering is an ongoing process that involves a complex interplay of the local, the regional, and the global. The process unfolds differently under changing historical circumstances that create boundaries anew. As we have seen, borderlands not only reflect global tectonic shifts in economy, but they also emerge as a dynamic site where actors respond to and shape policies in ways that have implications well beyond their immediate surroundings. Borderlands not only provide analytic opportunities to survey the pendulum of sociopolitical and economic tensions in a given region, but also offer a multilayered zone of contact, where global structural shifts transform interstate interactions and inform the way state actors bargain with the local interest groups in complex transactions.

Viewed from this angle, the borderlands between Turkey and Syria tell a unique story. Introduced as part of the broader refashioning of the world political order in the aftermath of the First World War, the border brought a formal end to the Ottoman order in the Middle East by introducing the principle of national sovereignty as envisioned by the Paris system. Yet both demarcation of the border and consolidation of the border regime constituted a much longer process that was hotly contested and negotiated throughout the 1920s and 1930s-many years after the formal agreements in Ankara in 1921 that had delimited the border on paper. Immediately after its creation, the Turkish-Syrian border became a backbone of contention that tested the powers of French colonialism and the limits of the Kemalist sphere of influence. Well into the late 1920s, however, the border remained largely porous, characterized by episodic brigandage and smuggling of goods placed under state monopoly. While Ankara certainly sought to undermine the economic links between southern Turkey and northern Syria it had often struggled to integrate its southern provinces into its national economy.

As the Great Depression gradually led to a heightened climate of economic competition across the globe, the once porous borders that had until then accommodated liberal economic exchanges became more susceptible to the influx of commodities that meandered around tightening border regulations in search of better markets. Strapped for cash due to narrowing global and domestic markets, states across the globe quickly became ever more cautious about the nature of border transactions and crossings. The introduction of tariffs, quotas, and other tools of protectionism to regulate cross-border transactions quickly redefined the position of states within a rapidly changing economic and political order, and the borderlands became the very site of this struggle. Analysis of commodity flows, such as textiles

\footnotetext{
${ }^{139}$ TNA, FO 371/17958/E593, "Extract from the Mersin Newspaper Yeni Mersin," 5 January 1934, 319.

${ }^{140}$ BCA, 490.1, 1455-38-1, July 1938, 40.

141"Hududumuzdaki Sıkı Tarassut," Türk Sözü, 3 September 1937, 1.

${ }^{142} \mathrm{CADN}$, Fonds Beyrouth, Services Spéciaux, 1SL/1/V, 2145, "Note Pour Monsieur l'Inspecteur General," Alep, 29 December 1937.
} 
and narcotics serves well to illustrate how state actors crafted policies that consolidated borders, while also demonstrating the ways in which local actors built cross-border coalitions in attending to lucrative illicit opportunities. Perhaps there is no better way after all to study something so spatially fixed like a border by exploring its interactions with commodities and people that constantly moved, often beyond its control.

Acknowledgments. This project has received funding from the European Research Council under the European Union's Horizon 2020 research and innovation program (grant 725269) as well as from Gerda Henkel Stiftung. I would like to thank Jordi Tejel, Alexander E. Balistreri, Alp Yenen, Orçun Can Okan, Nina S. Studer, Erdem Aydın, Sabri Ateş, and the three anonymous IJMES reviewers for their comments and suggestions.

Cite this article: Öztan RH (2020). The Great Depression and the Making of Turkish-Syrian Border, 1921-1939. International Journal of Middle East Studies 52, 311-326. https://doi.org/10.1017/S0020743820000021 